\title{
Corrigendum: Involvement of a non-human sialic acid in human cancer
}

\section{Annie N. Samraj, Heinz Läubli, Nissi Varki and Ajit Varki *}

Departments of Medicine, Pathology and Cellular and Molecular Medicine, Glycobiology Research and Training Center, University of California San Diego, La Jolla, CA, USA

*Correspondence: a1varki@ucsd.edu

Edited and reviewed by:

Adriane Regina Todeschini, Universidade Federal do Rio de Janeiro, Brazil

Keywords: Neu5Gc, sialic acid, antibodies, inflammation, tumor antigen, red meat

\section{A corrigendum on}

Involvement of a non-human sialic acid in human cancer

by Samraj AN, Läubli $H$ and Varki

A. Front Oncol (2014) 4:33. doi:

10.3389/fonc.2014.00033

Antibodies 14F7 and the corresponding anti-idiotype 1E10 (racotumomab, misspelled as racotumumab) were mistakenly conflated in this review. 14F7 reacts with (Neu5Gc)GM3, was recently humanized (1), but has not yet been tested in clinical trials. Racotumomab induced a human anti-(Neu5Gc)GM3 immune response, which correlated with longer median survival in non-small cell lung cancer (2). The first clinical trial result using racotumomab was actually published in 2002 (3). A phase III trial testing racotumomab in advanced non-small cell lung cancer began in 2011, and is currently recruiting (NCT01460472). These studies do not consider dietary Neu5Gc intake and incorporation as a variable that could affect (Neu5Gc)GM3 expression by human cancers.

\section{REFERENCES}

1. Fernández-Marrero Y, Roque-Navarro L, Hernández T, Dorvignit D, Molina-Pérez M, González A, et al. A cytotoxic humanized anti-ganglioside antibody produced in a murine cell line defective of N-glycolylated-glycoconjugates. Immunobiology (2011) 216:1239-47. doi:10.1016/j.imbio.2011.07. 004

2. Hernández AM, Toledo D, Martínez D, Griñán T, Brito V, Macías A, et al. Characterization of the antibody response against NeuGcGM3 ganglioside elicited in non-small cell lung cancer patients immunized with an anti-idiotype antibody. J Immunol (2008) 181:6625-34.

3. Alfonso M, Díaz A, Hernández AM, Pérez A, Rodríguez E, Bitton $\mathrm{R}$, et al. An anti-idiotype vaccine elicits a specific response to $\mathrm{N}$-glycolyl sialic acid residues of glycoconjugates in melanoma patients. J Immunol (2002) 168:2523-9.

Conflict of Interest Statement: The authors declare that the research was conducted in the absence of any commercial or financial relationships that could be construed as a potential conflict of interest.

Received: 02 April 2014; accepted: 04 April 2014; published online: 22 April 2014.

Citation: Samraj AN, Läubli H, Varki $N$ and Varki A (2014) Corrigendum: Involvement of a non-human sialic acid in human cancer. Front. Oncol. 4:83. doi: 10.3389/fonc. 2014.00083

This article was submitted to Molecular and Cellular Oncology, a section of the journal Frontiers in Oncology. Copyright $\odot 2014$ Samraj, Läubli, Varki and Varki. This is an open-access article distributed under the terms of the Creative Commons Attribution License (CC BY). The use, distribution or reproduction in other forums is permitted, provided the original author(s) or licensor are credited and that the original publication in this journal is cited, in accordance with accepted academic practice. No use, distribution or reproduction is permitted which does not comply with these terms. 